\title{
Oswajanie grozy. O humorze Nie-bajek Henryka Rzewuskiego
}

Katarzyna Puzio 
nAPTS Seria XIV 2008

\title{
Katarzyna Puzio
}

\section{Oswajanie grozy. O humorze Nie-bajek Henryka Rzewuskiego}

\begin{abstract}
$N$ ie-bajki to tytuł niewielkiego, mało znanego zbiorku gawęd autorstwa Henryka Rzewuskiego, wydanego w Petersburgu w roku 1851 jako tom pierwszy. Składa się nań siedem zróżnicowanych tematyczne i dość nierównych pod względem artystycznym tekstów, poprzedzonych obszernym $W$ stępem. Są to kolejno: Pan Kivitkiewicz, Ja gorę, Doktor, Kto lepiej wypije, Upominek duchów, Wzbogacenie i Zamek w Szwecji. Tom drugi nigdy nie został wydany, prawdopodobnie miał zawierać sześć opowiadań ogłoszonych w „Tygodniku Petersburskim” również w roku $1851^{1}$.

Petersburski pierwodruk to jedyne, jak dotąd, pełne wydanie Nie-bajek, choć w wieku $\mathrm{XX}$ pojawily się przedruki pojedynczych gawęd: Ja gorę w zbiorze Polska nowela fantastyczna przygotowanym przez Juliana Tuwima ${ }^{2}$ oraz Ja gorę i Ko lepiej wypije w znacznie nowszej antologii romantycznej gawędy szlacheckiej Andrzeja Waśkỉ. Jakkolwiek pierwszy z wymienionych utworów zaliczany jest do klasyki naszej noweli fantastycznej, to ta część dorobku autora Pamiątek Soplicy nie cieszy się zainteresowaniem zarówno badaczy jego języka ${ }^{4}$, jak
\end{abstract}

${ }^{1}$ Są to następujące opowiadania (wymienione w kolejności wydania w „Tygodniku Petersburskim”): Odmłodnienie (nr 48/49), Karzet opiekun (nr 52/53), Żywi i umarli (nr 57), Koty (nr 58/59), Kartownicy (nr 74), Pan Dubrouski (nr 76/77).

${ }^{2}$ Zob. Polska nowela fantastyczna, zebr. J. Tuwim, t. 1, Warszawa 1953.

${ }^{3}$ Zob. Romantyczna gawęda szlachecka. Antologia, wyb. i opr. A. Waśko, Kraków 1999.

${ }^{4}$ Zob. B. Bartnicka, O jezyku Henryka Rzeuruskiego, Kielce-Warszawa 1996; eadem, O jezyku Henryka Rzewuskiego ciag dalszy, Kielce-Warszawa 1998. Bartnicka materiał do swej pierwszej książki zaczerpnęła wyłącznie z powieści historycznych autora Listopada, a w kontynuacji poprzedniego tomu poszerzyła materiał egzemplifikacyjny o teksty Mieszanin obyczajowych, Easki i przeznaczenia oraz Pazia złotowtosego. 
i nurtu sarmackiego w literaturze XIX wieku ${ }^{5}$. Przyczyną tego zapomnienia wydaje się tendencja do traktowania Nie-bajek, niewątpliwie pozycji w twórczości Rzewuskiego odrębnej, nieporównywalnej z arcydzielnymi Pamiątkami..., jako utworu właściwie niegodnego uwagi' ${ }^{6}$. Zapewne zaważył też sąd Zygmunta Szweykowskiego, który, w skądinąd wciąż cennym opracowaniu poświęconym powieściom historycznym Rzewuskiego, zdecydowanie krytycznie odniósł się do Nie-bajek7. Sam zaś Rzewuski wydawał się podkreślać wręcz ich łączność $\mathrm{z}$ utworami historycznymi, chociażby przez wprowadzenie do opowiadania ramowego postaci Pana Cześnika Parnawskiego jako narratora pierwszej gawędy zbioru.

Nie-bajki, a właściwie jedna z nich - Ja gorę — została jednakże doceniona przez badaczy polskiej recepcji europejskiego gotycyzmu, a przede wszystkim Marię Janion — autorkę nazwy "gawędowy gotycyzm”. Również Ryszard Przybylski, omawiając z reguły dość krytycznie polskie próby powieści gotyckiej, zauważa z zadowoleniem powstanie owego "gawędowego gotycyzmu”, który stworzył „naprawdę znakomite utwory, takie jak Ja gorę Rzewuskiego"'.

Wspomniany już wcześniej Wstęp stanowi ramę kompozycyjną dla zbioru, służąc przede wszystkim przedstawieniu sytuacji narracyjnej, realizującej podstawowy stereotyp sytuacji gawędowej — intymnej „kominkowej” czy „stolikowej” sytuacji opowiadania:

Wstano od stołu, postawiono stolik na środku bawialnego pokoju, na nim butelkę starego tokaju i kieliszek, gdyż opowiadaniem gardło się suszy, przy stoliku postawiono krzesło. Na nim posadzono Cześnika. Wszyscy siedli wokoło niego. Stary się skłonił wszystkim, usiadł w krześle i tymi odezwał się słowy ${ }^{10}$.

\footnotetext{
${ }^{5}$ Zob. najnowsze opracowanie poświęcone temu zagadnieniu: B. Szleszyński, Przymierzanie kontusza. Henryk Rzeuuski i Henryk Sienkiewicz - najwybitniejsi twórcy XIX-uiecznego nurtu sarmackiego, Warszawa 2007.

${ }^{6}$ Zob. A. Ślisz, Henryk Rzewuski. Życie i poglądy, Warszawa 1986, s. 255-256.

7 Szweykowski stwierdzil, że w Nie-bajkach Rzewuski nie utrzymał się „chociaż na poziomie poprawności", tracąc zupełnie oryginalność. Całej tej działalności nie warto, według krytyka, byłoby w ogóle wspominać, gdyby nie wzgląd na dalszą twórczość ściśle historyczną, do której wprowadził Rzewuski pewne sensacyjne bądź demoniczne motywy i postaci. Wydaje się, że krytyk popełnił w swej ocenie zasadniczy błąd, zakładając, że utwory Nie-bajek — pełne szablonów, przypominające istną mozaikę wpływów - miały wystąpić w tradycyjnie przypisywanej tego typu utworom funkcji, tj. budzić grozę. Co za tym idzie, ich niewątpliwy komizm uznał za coś niezamierzonego - rodzaj wypadku przy pracy, doszukując się w tych utworach obcego im z gruntu dydaktyzmu, pisząc o tezach religijno-filozoficznych lub społeczno-obyczajowych, jakie w nich Rzewuski zawiera. (Zob. Z. Szweykowski, Powieści historyczne Henryka Rzewuskiego, Warszawa 1922, s. 242-245).

${ }^{8}$ M. Janion, Forma gotycka Gombrowicza, w: eadem, Goraczka romantyczna, Warszawa 1975, s. 229-230.

${ }^{9}$ A. Witkowska, R. Przybylski, Romantyzm, Warszawa 1998, s. 110.

${ }^{10}$ H. Rzewuski, Wstęp do: Nie-bajki, op. cit, s. 9.
} 
Narrator Wstępu, młodzieniec utożsamiany z autorem, objaśnia też kulisy powstania Nie-bajek, przywołując pewien jakoby prawdziwy epizod swojej biografii. Otóż powracając w 1811 roku z pierwszej podróży na Zachód, do Szwajcarii, zatrzymał się w Krakowie i spędził tam późną jesień oraz zimę na przełomie roku 1811 i $1812^{11}$. Nudę kolejnych długich zimowych wieczorów adwentu wypełniały gawędy przedstawionych $z$ imienia i nazwiska bywalców krakowskich salonów, których łączyło jedno: byli to ludzie należący do minionej epoki, czasów stanisławowskich, i o nich przede wszystkim rozprawiający. Historie o strachach, diabłach i upiorach stanowily ważną część „skarbnicy naszego ducha narodowego”, oralnej kultury szlacheckiej, czego dowody znajdziemy w opowiadaniach Józefa Maksymiliana Ossolińskiego ${ }^{12}$ czy Kazimierza Władysława Wójcickiego ${ }^{13}$, a także w Upominku duchów, gdzie czytamy:

Owoż tedy, jak to bywa we zwyczaju w starych zamkach, rozmowa wieczorna skierowała się sama z siebie ku tym rzeczom nadzwyczajnym [...]. Mówiono o upiorach, o strachach, o umarłych, pokazujących się pozostatym przyjaciołom i krewnym, i tak dalej ${ }^{14}$.

Jedną z zasad, jakie miały obowiązywać uczestników zabawy, było niepodważanie prawdziwości żadnego opowiadania, nawet najdziwniejszego:

Zresztą niech sobie będzie anegdotą, opowieścią, częścią dziejów ojczystych, obrazem jej obyczajów, nawet rzeczą zupełnie fantastyczną mniejsza o to, byle tylko nie było wiadome drukarskim prasom ${ }^{15}$.

Sam tytuł, jaki zbiorkowi nadał Rzewuski, zdaje się mówić: „to nie są bajki — to prawda" i stanowić autorski komentarz do utworów w nim zebranych, które z wyjątkiem pierwszego są właśnie opowiadaniami fantastycznymi. Podobną funkcję co tytuł pełnić miało też motto z Szekspira umieszczone na stronie tytułowej: „All is true”, a utwór Rzewuskiego wpisywał się tym samym w starą, jeszcze osiemnastowieczną konwencję powieściową stosowania zabiegów uwierzytelniających fikcję. Temu celowi służy też wprowadzenie narratora konkretnego i formy opowiadania naocznego świadka.

Jeśli jednak wcześniejsze gawędy Rzewuskiego - Trybunał lubelski czy Ksiądz Marek — ocierały się o fantastykę tylko przelotnie, to niewątpliwy i wyraźny jest już w Pamiąt-

1 Zob. A. Ślisz, Henryk Rzeuuski..., op. cit., s. 27-28. O „grze w prawdziwe - prawdopodobne nieprawdziwe" u Rzewuskiego zob. też B. Szleszyński, Przymierzanie kontusza..., op. cit., s. 120-121.

${ }^{12}$ Zob. J. M. Ossoliński, Wieczory badeńskie, czyli Pourieści o strachach i upiorach, przedm. A. Małachowski, Warszawa 1970.

${ }^{13}$ Zob. K. W. Wójcicki, Stare gauędy i obrazy, t. 3-4, Warszawa 1840.

${ }^{14}$ H. Rzewuski, Upominek duchów, w: idem, Nie-bajki, op. cit., s. 87.

${ }^{15}$ Idem, Wstep, op. cit., s. 6. 
kach Soplicy ton humorystyczny, którego swoistość próbowali określić zarówno Szweykowski, jak i Maria Żmigrodzka w doskonałych wstępach do kolejnych edycji zbioru ${ }^{16}$. Humor Nie-bajek jest jednak zupełnie innego rodzaju, mają one bowiem wylącznie charakter zabawy literackiej, bez jakichkolwiek podtekstów ideowych ${ }^{17}$.

$\mathrm{Na}$ szczególna uwagę zasługują trzy gawędy zbioru: Ja gorę, Kto lepiej wypije i Upominek duchów, o których wyjątkowości nie tylko w obrębie Nie-bajek, ale i całej naszej dziewiętnastowiecznej literatury stanowi oryginalne połączenie rubasznego i dobrodusznego humoru z rodzimą sarmacko-ludową fantastyką lub fantastyką w „stylu angielskim", co czyni je przykładem udanej, polskiej transformacji gotyku ${ }^{18}$. Raczej bezcelowe wydają się dociekania, czy Rzewuski w Nie-bajkach „dał upust swym skłonnościom do rzeczy nadprzyrodzonych, niepojętych, tajemniczych" ${ }^{19}$ i czy są one głosem protestu przeciw wylącznie empirycznemu, racjonalnemu objaśnianiu rzeczywistości. Trzeba bowiem wystrzegać się pewnego niebezpiecznego nieporozumienia, którego istotę wyjaśnię, cytując Rogera Caillois:

Założeniem opowiadań fantastycznych nie jest bynajmniej uwierzytelnienie istnienia świata widm, zjaw i duchów. [...] Literatura fantastyczna w założeniu swoim dzieje się na płaszczyźnie czystej fikcji. Jest przede wszystkim grą człowieka ze strachem ${ }^{20}$.

Uciekanie się do fikcji oznaczało, że nie usiłuje się nikogo przekonać i że autor nie występuje sam w roli wiarygodnego świadka. Sęk w tym, że narratorzy Rzewuskiego podkreślają, czego gatunek gawędy wręcz wymaga, iż opowiadają o tym, czego doŚwiadczyli (Zamek w Szwecji), co zasłyszeli (Kto lepiej wypije), czego byli świadkami (Ja gorę). Powtarzane co chwila zaklęcia typu:

Jak mnie tu państwo widzicie, byłem z innymi przytomny tej rozmowie ${ }^{21}$;

16 Zob. Z. Szweykowski, Wstęp, w: H. Rzewuski, Pamiątki Soplicy, Wrocław 2004, s. XXVIII-XXXII. O zasadzie humorystycznej stylizacji gawęd pisała Maria Żmigrodzka (zob. eadem, Karmazyn, palestrant $i$ wiek XIX, [wstęp do:] H. Rzewuski, Pamiątki Soplicy, Warszawa 1961; eadem, Przez wieki idąca powieść. Wybór pism o literaturze XIX i XX wieku, opr. M. Kalinowska, E. Kiślak, wst. E. Kiślak, Warszawa 2002). Por. też W. Weintraub, Między Plutarchem a Sowizdrzatem: „Pamiatki Soplicy”, w: Literatura, komparatystyka, folklor. Księa poświęcona Julianoui Krzyżanowskiemu, red. M. Bokszczanin, S. Frybes, E. Jankowski, Warszawa 1968.

17 Tak samo postrzega charakter Nie-bajek Andrzej Waśko. Zob. Romantyczna gawęda szlachecka..., op. cit., s. 336.

18 Utworem, który jest pod tym względem bliski trzem gawędom z Nie-bajek, może być Zapatan Władysława Łozińskiego.

${ }_{19}$ A. Ślisz, Henryk Rzeunuski..., op. cit., s. 256.

${ }^{20}$ R. Caillois, Od baśni do science-fiction, w: idem, Odpowiedzialność i styl. Eseje, wyb. M. Żurowski, tł.

J. Błoński, Warszawa 1967, s. 39.

${ }^{21}$ H. Rzewuski, Ja gore, w: Polska nowela fantastyczna, zebrał J. Tuwim, t. 1, Kraków 1976, s. 77. 
Nie powiem, że widziałam, co opowiadać będę, ale temu wierzę, jakbym sama na to patrzała. Bo to słyszałam od bardzo poczciwego czlowieka $^{22}$ -

irytują czytelnika i zdają się świadczyć o cichej kpinie, gdy odnoszą się np. do świadectwa pijaka. Rzewuski nie odżegnuje się od wiary w duchy, ale i nie wyrzeka się żartobliwego podejścia do nich, a podobną dwuznaczność można zaobserwować w niemal każdej z gawęd.

W Ja gore autor wykorzystal konwencjonalny schemat zamku i tajemnicy z przeszłości, kładącej się cieniem na życie bohatera, jak też niemal pełny katalog elementów składających się na podstawowy stereotyp gotycki w literaturze, począwszy od motywu nawiedzenia przez charakterystyczne postaci „łotra gotyckiego”, prześladowanej dziewicy, jej ukochanego i mnicha (w tym wypadku księdza), średniowieczną zbrodnię i motyw odkupienia, gdy dusza potępiona domaga się dokonania pewnej czynności dla osiągnięcia wiecznego spokoju.

Lecz na tym podobieństwa się kończą, co nie pozwala uznać tej gawędy za kolejny utwór wtórny wobec europejskiego gotycyzmu. Zemsta i zbrodnia są wprawdzie jeszcze trochę w „stylu angielskim”, ale zarówno duch, jaki i rzeczywiście istniejący zamek „staroświeckim trybem murowany” i egzorcyzmy są jak najbardziej rodzime. Całość zaś „niesamowitej opowieści” została świetnie osadzona w polskim kolorycie lokalnym. W zamku „straszy” ostatni książę zatorski Wilibald, spokrewniony niewątpliwie ze słynnymi postaciami magnackich sadystów i okrutników (jak np. Mikolaj Potocki). Podstępem, obiecując przebaczenie, zwabił on do swej siedziby córkę, która bez jego zgody wyszła za polskiego rycerza, a także jej męża i kieleckiego proboszcza, który połączył ich sakramentem. Od tamtej pory słuch po nich zaginął. Jak się okaże, wszyscy troje umarli śmiercią głodową, zamurowani żywcem w jednej z ukrytych komnat zamku. Podobnych historii notuje Leonard Pełka w Polskiej demonologii ludowej wiele, wyróżnia nawet osobną grupę zjaw i widm zamkowych, będących duchami dawnych właścicieli zamków rycerskich i rezydencji magnackich. Ich często burzliwe i tragiczne losy znalazły odzwierciedlenie w lokalnej tradycji podaniowej, w której nierzadko obecne są motywy zamurowania żywcem jako zemsty za nieposłuszeństwo lub cudzołóstwo ${ }^{23}$.

Jednak właściwym tematem gawędy nie są smutne dzieje kochanków z końca XV wieku, ale sposób, w jaki duch dawnego pana zamku po trzystu niemal latach od tragicznych wydarzeń nęka swą ofiarę i jak się o tym opowiada: z lagodnym smutkiem i dobrodusznym humorem. Ofiarą jest poczciwy, Bogu ducha winny ukraiński szlach-

${ }^{22}$ Idem, Kto lepiej urypije, w: idem, Nie-bajki, op. cit., s. 67.

${ }^{23}$ Zob. L. Pełka, Polska demonologia ludowa, Warszawa 1987 (rozdz. V Zjawiska parademoniczne). Zob. te ż

B. Wernichowska, M. Kozłowski, Duchy polskie, czyli krótki przewodnik po nawiedzonych zamkach, dworach i pałacach, Warszawa 1985. 
cic o znaczącym nazwisku Pogorzelski herbu Krzywa. Jako człowiek uczciwy i ,wielce biegły w gospodarstwie" zarządzał on kluczem samsonowskim w dobrach biskupa krakowskiego Kajetana Sołtyka ${ }^{24}$. Otrzymał zadanie odnowienia opuszczonego od lat zamku, który biskup chciał uczynić swą letnią rezydencją. Choć wieśniacy mawiali, „że w nocy coś tam straszy, że jakby z wnętrz zamkowych dawały się słyszeć jęki” "25, Pogorzelski stosownie do rozkazów rozpoczął restaurację zamku. Od tego momentu słowa: ,ja gorę", wypowiadane przez niewidzialną istotę, towarzyszyły każdej najbłahszej czynności bohatera, przypominając o nieprzerwanej, „drobiazgowej” męce zamieszkującego Zator złego ducha. Niepowtarzalny komizm sytuacji wytwarza się w zestawieniu skargi ducha i codziennych czynności, w kontraście demonizmu i trywialności ${ }^{26}$, a efekt komiczny potęguje powtarzalność: „Panie Pogorzelski, WPan się modlisz, a ja gorę”, „Panie Pogorzelski, WPan się wybierasz w pole, a ja gorę”, „Panie Pogorzelski, WPan chcesz pić herbatę, a ja gorę". Głos ducha towarzyszy Pogorzelskiemu i w dzień, i w nocy, nie dając ani na chwilę o sobie zapomnieć: „Panie Pogorzelski, WPan się wybierasz na Ukrainę, żeby się mnie pozbyć, nie będzie nic z tego. WPan się pakujesz, a ja gorę". I choć rubaszny, wesoły i powszechnie z tych powodów lubiany szlachcic popadł w czarną melancholię, to przecież trudno nazwać prześladującego go ducha groźnym - raczej uciążliwym. Słowa jego skargi brzmią tak swojsko i przejmująco, że budzi po prostu litość, zapominamy nawet, iż to skarga mordercy, który dla urażonej dumy skazal na śmierć w męczarniach własną córkę; umarł obłożony kościelną klątwą, z bluźnierstwem na ustach. Właściwy tego typu gotyckim opowieściom nastrój przerażenia zostaje zniwelowany za sprawą humoru, groza — „oswojona”; także dzięki kreacji bohatera jako przedstawiciela szlacheckiej przeciętności, Pana Pogorzelskiego - bohatera, którego darzymy niekłamaną sympatią — śmieszność bynajmniej nie oszczędza. Można przypisać tej postaci „komizm sympatyczny”27, co potwierdza też jego przedziwna zdolność przyciągania „złego”, jeśli dawać wiarę opowieściom o dwu magicznych przedmiotach — jak się okazało: czartowskich darach — które stały się jego własnością: o fuzji, która pozwalała ustrzelić zwierzynę, o jakiej pomyślał myśliwy, i o srebrnym groszu, który zawsze wracał do właściciela. Zdradzają one naiwność i zabobonność szlachcica, właściwą ponoć wszystkim Rusinom, a może i jego skłonność do konfabulacji.

Zgoła groteskowe rysy zyskuje „zły duch”, który „bierze udział” w mszy odprawionej w zamku, powtarzając słowa kapłana i wiernych:

\footnotetext{
${ }^{24}$ Także w innych gawędach zbioru Rzewuski wprowadza postaci historyczne jako bohaterów drugoplanowych: hetmana wielkiego koronnego Jana Klemensa Branickiego w Kto lepiej uүpije czy generała Karola Kniaziewicza w Upominku duchów.

${ }^{25}$ H. Rzewuski, Ja gore, w: Polska nowela fantastyczna, op. cit., s. 75.

${ }^{26}$ Zob. na temat Ja gore, w: M. Janion, Forma gotycka Gombrowicza, op. cit., s. 229-230.

${ }^{27}$ Zob. J. Kleiner, Z zagadnień komizmu, w: idem, Studia z zakresu teorii literatury, Lublin 1961, s. 84.
} 
— Wszelki duch Pana Boga chwali! — I my go chwalimy — odezwali się wszyscy. Wtem nie wiedzieć skąd, pojedynczy głos daje się słyszeć: - Panie Pogorzelski, wy go chwalicie, a ja gorę ${ }^{28}$.

Właściwie ład świata nie został zburzony w wyniku działania irracjonalnych sil, brak w tekście środków „negatywnej niezwykłości”, jak ciemność, milczenie, pustka. Wszystko kończy się dobrze, po pogrzebaniu odnalezionych szczątków ofiar Wilibalda i odprawieniu przez biskupa egzorcyzmów do zamku wraca spokój.

W Upominku duchów miejscem niesamowitych zdarzeń, o których opowieść snuje Kasztelanowa Woroniczowa przy robieniu pończoszki (sic!), jest znowu zamek, tym razem na Ukrainie, ale ani nawiedzony, ani gotycki:

pół-zamek, pół-dom wiejski, drewniany na podmurowaniu, obszerny, staroświecki, niejeden szturm wytrzymał w czasach Chmielnickiego. Przy tym zamczysku, otoczonym wałami i ostrołukami, był ogród wcale piękny, a u nóg jego płynąl romantyczny Teterew ${ }^{29}$.

Oto pewnego wieczoru jego mieszkanka, która przywykła co dzień przyjmować na obiedzie czterdzieści osób, nudziła się sama w domu, więc uczyniła wotum, że będzie rada każdemu gościowi, jaki się zjawi. Od tego momentu wydarzenia rozwijają się jak w baśni o spełnianiu życzeń. Na wezwanie spod kaflowego pieca wytoczył się orszak niezwyklych, uroczych i dobrze wychowanych istot przypominających krasnoludki albo maleńkie ludziki z dziecięcej szafy z zabawkami, które nawiedzają dom radcy sanitarnego Stahlbauma w Dziadku do orzechów Ernesta Teodora Amadeusza Hoffmanna ${ }^{30}$. Efekt niespodzianki pogłębia mechanizm zawiedzionego oczekiwania czytelnika, który zgodnie $z$ sugestią tytułu spodziewal się wizyty innego rodzaju istot. $Z$ pewnością nie były to złe duchy, gdyż na tarczach miały znak krzyża. Tworzyły barwny orszak złożony z książęcej pary, dworzan w strojach kapiących złotem oraz hufca rycerzy w srebrnych zbrojach. Wszyscy ucztowali i bawili się na środku komnaty do rana, a żegnając grzecznie gospodynię, podarowali jej maleńki, pięknie zdobiony, srebrny półmisek, który następnie powiększył się do normalnych rozmiarów. Baśniowy charakter niesamowitego zdarzenia wyklucza jakąkolwiek grozę czy tajemnicę, choć ma ono miejsce nie w ba-

\footnotetext{
${ }^{28} \mathrm{H}$. Rzewuski, Ja gore, op. cit., s. 78.

${ }^{29}$ Idem, Upominek duchów, w: idem, Nie-bajki, op. cit., s. 83.

${ }^{30}$ Hoffmanizmu utworów Rzewuskiego nie należy raczej przeceniać, jest w istocie dość powierzchowny: akcja rozgrywa się w konkretnym miejscu i czasie, a w odróżnieniu od powieści gotyckiej nazwy miejscowe są prawdziwe (Warszawa, Zator); funkcję odniesienia czasowego pełnią zwykle wydarzenia historyczne: konfederacja barska w Ja gorę i insurekcja kościuszkowska w Upominku duchów, co wraz $z$ odtwarzaniem codziennego życia bohaterów uprawdopodabnia realistyczne tło zdarzeń. Zob. E. Zarych, Fantastyka w utuorach E. T. A. Hoffmanna, „Teksty Drugie” 1998, z. 5, s. 56-57.
} 
śniowym świecie cudów, czarodziejów i dobrych wróżek, ale w świecie przedstawionym jak najbardziej realistycznie. Dlaczego scena ta budzi co najwyżej lekkie zdziwienie gospodyni? Czy dlatego, że tradycja wierzeniowa, w której więź łącząca świat żywych i umarłych zakłada całkowitą zgodę na istnienie zaświatów, osłabia indywidualny lęk metafizyczny?31 Bynajmniej; nawet uczony proboszcz, słuchający opowieści i rozprawiający o tajemnym stosunku między światem dotykalnym a niewidzialnym, który nie podlega rachunkom ludzkiego rozumu, nie przyjmuje nic na wiarę i żąda świadectwa prawdziwości opowieści. Materialnym dowodem jest przechowywany w rodzinie półmisek, a naocznym świadkiem cudownego zdarzenia dawna, siedmioletnia wówczas wychowanka pani Woroniczowej. Paradoksalnie nic nie wskazuje na zaświatowe pochodzenie upominku duchów, nie jest to przedmiot magiczny ani w ogóle niezwykły. Zastanawiający jest też erudycyjny przypis pod tekstem, informujący, że z prawnego punktu widzenia świadectwo siedmiolatki jest nieważne.

Trzecia z humorystycznych gawęd Rzewuskiego (narratorką znów jest kobieta!) przedstawia osobliwy turniej, do jakiego stanął pod hasłem zawartym w tytule Kto lepiej wypije szlachcic Komarzewski z... samym Szatanem. Ten słynny pijak, którego nikt w całej Polsce nie przepil, bo tak mocną miał głowę, że nawet po stu butelkach węgrzyna wypitych w 12 godzin nie był pijany, wyrazil pewnego razu pół żartem życzenie, by choć raz poczuć się pijanym, a w tym celu odważyłby się pić nawet $\mathrm{z}$ diabłem. Wyzwane piekło odpowiedziało grzmotami, a w sam Wielki Piątek znaleziono Komarzewskiego pijanego w ulicznym rynsztoku. Choć niechętnie, po czterech dniach spędzonych bez przytomności i tygodniowej chorobie, musiał on wreszcie wyjawić, jak do tego doszło. Przyjął zaproszenie na biesiadę od nieznajomego Niemczyka, którego pan - jakiś Starosta chciał się z Komarzewskim zmierzyć. Kiedy nasz bohater zorientował się, że to nie żart i gospodarz — szkaradny Niemiec siedzący na beczce — to istotnie diabeł, nie zmieszał się zbytnio i pil dalej, bo „wino dobre mi się zdało, ale tak ciepłe, jakby było grzane" 32 .

Rzewuski nawiązal do znanego z ludowej bajki magicznej wątku zakładu człowieka $\mathrm{z}$ diabłem ${ }^{33}$, ale w niej to kusiciel przegrywał i był postacią wykpioną, a jego przeciwnik dzięki swej przemyślności i rozwadze zwyciężał zło. W gawędzie Rzewuskiego Komarzewski zostaje przez diabły pokonany — po raz pierwszy w życiu przecież się upil, ale złe duchy wymierzyły mu karę nie za pijaństwo, tylko za dumę, która nie pozwoliła mu uznać Szatana za swego króla i wypić jego zdrowia. Postać ta, obiektywnie rzecz biorąc, moralnie ujemna, opój, któremu od trzydziestu lat nie zdarzyło się napić wody, bynajmniej nie została przedstawiona w sposób zdecydowanie satyryczny. Komarzew-

${ }^{31}$ Zob. M. Delaperrière, Fantastyka czy cudowność ( $Z$ badań porównawczych nad polską uyobraźniq̨ literackq), „Ruch Literacki” 1990, z. 1, s. 13.

${ }^{32}$ H. Rzewuski, Kto lepiej wypije, op. cit., s. 79.

${ }^{33}$ Zob. J. Krzyżanowski, W świecie bajki ludowej, Warszawa 1980, s 72. 
ski bowiem obdarzony został wieloma cechami cenionymi w środowisku szlacheckim, jak: cięty dowcip, którego używał także przeciw możnym ${ }^{34}$, brawura i fantazja (spoliczkowal diabła, który go obraził), i dlatego potraktowany został przez gawędową narratorkę z humorem rozgrzeszającym, a nie wystąpil tu typ komizmu degradacyjne$\mathrm{go}^{35}$. Autor nie mógł włożyć w usta generałowej Mokronowskiej słów otwartej krytyki, bo należała ona do środowiska, które w pijaństwie nie widziało nic zdrożnego, a wręcz otaczało podziwem:

Kto mógł pić duzo, bez stracenia przytomności, ten miał wiele przyjaciół i był pewny znaczenia i losu. Jeżeli o kim mówiono: „nie ma takiego, który mógłby jemu dotrzymać placu z kielichem”, to była największa pochwała, jaką można było go wsławić przed publicznością ${ }^{36}$.

Postać pana Komarzewskiego ukształtowana została niewątpliwie na wzór znanych z historii barwnych figur pijaków i hulaków, doskonale osadzona w obyczajowych realiach czasów saskich Rzeczypospolitej szlacheckiej. Dokonania najsłynniejszych „kielichowych” zebrał Jędrzej Kitowicz w Opisie obyczajów za panowania Augusta III, przywołując na przykład postać Adama Małachowskiego, którego goście musieli wychylać do dna ogromny kielich albo dolewano im ponownie, co kończyło się zwykle utratą zdrowia, a nierzadko nawet życia ${ }^{37}$.

Mimo wszystko bohater gawędy zostal dość dotkliwie ośmieszony za sprawą rodzaju diabelskiej, raczej odrażającej kary, jaka go spotkała:

Wtem ćma diabłów różnego kształtu i wzrostu na mnie się rzuciła, [...], a potem, gdzie znaleźli otwór w moim ciele, wetknęli tam miech i zaczęli dmuchać, że coraz więcej nadęciem rozszerzałem się, tak że wkrótce zrobiło się dla mnie ciasno w obszernej tej izbie... ${ }^{38}$

W tym opisie rubaszność szlachecka łączy się z osobliwą groteską i makabrą. Fizycznie odpychający diabeł przeraża, ale w równym stopniu także śmieszy, gdyż jest polski do szpiku kości, nie tylko dlatego, że występuje w niemieckim stroju ${ }^{39}$, lecz

\footnotetext{
${ }^{34} \mathrm{~Np}$. w przymówce do hetmańskiego siostrzana — księcia wojewodzica smoleńskiego, który częstował gości śmierdzącym siarką cienkuszem reńskim. Zob. H. Rzewuski, Kto lepiej wypije, op. cit., s. 70.

35 Zob. na temat komizmu humorystycznego i degradacyjnego np. J. Ziomek, Parodia jako problem retoryki, w: idem, Rzeczy komiczne, Poznań 2000, s. 86-87.

${ }^{36} \mathrm{H}$. Rzewuski, Kto lepiej uүpije, op. cit., s. 68.

37 Zob. J. Kitowicz, Opis obyczajów' za panowania Augusta III, opr. R. Pollak, Wrocław 1970 (BN I 88), s. $443-450$.

${ }^{38}$ H. Rzewuski, Kto lepiej wypije, op. cit., s. 81.

39 „Już w końcu XVII stulecia polski czart uosabiał Niemca” (M. Rożek, Diabeł w kulturze polskiej, Warszawa 1993, s. 201).
} 
przede wszystkim dlatego, że pije jak polski szlachcic i ani myśli porywać pijanicy Komarzewskiego do piekła, a przy tym przypisano mu również ten sam rubaszny sposób mówienia:

— A trutniu jakiś — krzyknął szatan - moje wino pijesz, a mnie za swego pana przyznać nie chcesz! [...] Natarmoś-no tego głupca, żeby się nauczył do mnie przyzwoicie mówić ${ }^{40}$.

Autor zdaje się też drwiąco mrugać do czytelnika ponad głową narratora, bowiem konstrukcja narracji rodzi podejrzenie, że przygoda Komarzewskiego, którą on sam relacjonuje, to być może jedna $z$ wielu opowieści pijaków widujących duchy i diabły wskutek zamroczenia trunkiem! Wyraźnie komiczna dwuznaczność widoczna jest $\mathrm{w}$ traktowaniu materii religijnej — w kontraście między powierzchowną pobożnością bohatera a jego pijaństwem. Wiara nie przeszkadza Komarzewskiemu w biesiadowaniu w Wielki Piątek z diabłem, podczas gdy za największy swój grzech uznaje zlekceważenie obowiązku spowiedzi ${ }^{41}$.

Jedynym utworem w naszej literaturze tego okresu, który można do Nie-bajek porównać pod względem humoru, kompozycji (technika szkatulkowa), tematów, ale już nie sposobu traktowania fantastyki, są Wieczory badeńskie, czyli Powieści o strachach i upiorach Józefa Maksymiliana Ossolińskiego. Jednak raczej nie może być mowy o ich wpływie na powstanie i ksztalt utworu Rzewuskiego. Wieczory... powstały wprawdzie u schyłku wieku XVIII (prawdopodobnie w latach 1793-179442), ale zostały opublikowane dopiero w roku 1852. Wydanie z 1970 roku przygotowane przez Spóldzielnię Wydawniczą „Czytelnik” oparto na tej pierwszej i jedynej dziewiętnastowiecznej edycji książkowej ${ }^{43}$. We Wstępie, podobnie jak u Rzewuskiego, zawarta jest relacja o autentycznym zdarzeniu, jakie stanowiło inspirację twórczą dla autora, a mianowicie o zebraniach grona Polaków-kuracjuszy w Baden, uprzyjemniających sobie opowiadaniem bajek o upiorach długie, jesienne wieczory „w końcu zeszłego stulecia”. Wstęp pełni rolę opowiadania ramowego, w którego obrębie kolejne teksty funkcjonują jako zacytowane fabuly. Wieczory... to pierwszy w naszej literaturze przypadek pojawienia się narracyjnej sytuacji gawędy ${ }^{44}$. Wszystkie opowiadania cyklu łączy, jednocześnie odróżniając je od Nie-bajek, programowo zdeklarowany we Wstępie oświeceniowej proweniencji

\footnotetext{
${ }^{40}$ H. Rzewuski, Kto lepiej uypije, op. cit., s. 80.

${ }^{41}$ Wśród postaci historycznych opisanych przez Kitowicza byli też „pobożni pijacy”, jak np. pan Borejko, kasztelan zawichojski, który lubił pijać z duchownymi.

${ }^{42}$ Zob. hasło Ossolinski Józef Maksymilian Jan, w: Bibliografia literatury polskiej „Nouy Korbut”, t. 5: Oświecenie, opr. E. Aleksandrowska z zesp., Warszawa 1967, s. 454-460.

${ }^{43}$ Fragmenty ukazywały się w „Przyjacielu Ludu” w latach 1844-1846.

${ }^{44}$ Na prekursorski w stosunku do późniejszej gawędy prozą kształt Wieczorów... zwróciła uwagę już Maria Jasińska — zob. eadem, Narrator w powieści przedromantycznej (1776-1831), Warszawa 1956, s. 62.
} 
dydaktyzm (walka z saską ciemnotą i zabobonem), sceptycyzm w ocenie zjawisk nadprzyrodzonych oraz dominująca nad całością zironizowana narracja autorska ${ }^{45}$.

Nie-bajki nazwano kiedyś „sarmackimi horrorami”" ${ }^{46}$, ale lektura trzech omówionych powyżej tekstów nie pozostawia wątpliwości, że celem ich autora nie było straszenie czytelnika. Ich fabuły wykluczają tajemnicę, narratorzy nie rozwikłują żadnych zagadek, brak zupełnie nastrojowego, groźnego tla. Od początku wiemy, do kogo należy głos powtarzający: ,ja gorę”, bo zanim się pojawil, poznaliśmy historię zbrodni księcia zatorskiego. Po wyzwaniu, jakie rzuca piekłu Komarzewski, nikt nie ma wątpliwości, kim jest rzekomy starosta zapraszający go na ucztę. Rzewuski nie tworzy wysokiej klasy fantastyki, będącej w definicji Bogusława Doparta

dziedziną wyrafinowanej niepewności, przeczucia niespójności świata, dwuznaczności świadectw naszych zmysłów, niepokoju o sens doświadczeń świata i siebie samego ${ }^{47}$.

Motywy fantastyczne w omawianych gawędach potraktowane zostały w sposób ironiczno-humorystyczny i wtopione w realistyczny obraz polskiej rzeczywistości ${ }^{48}$. Pozostaje żałować, że w nurcie "gawędowego gotycyzmu” nie pojawiło się więcej równie ciekawych utworów, gdyż powstał on na gruncie gatunku literackiego nigdzie poza Polską niespotykanego i nie był naśladowczy w stosunku do gotycyzmu zachodnioeuropejskiego ${ }^{49}$. O ile (według Marii Janion) słabość polskiego gotycyzmu w ogóle wynikała z kulturowych i obyczajowych różnic, dzielących Polskę i Anglię, o tyle właśnie odrębny i oryginalny styl, jakim odznaczała się polska kultura szlachecka, stanowił siłę "gawędowego gotycyzmu" oswajającego grozę.

${ }_{45}$ Zob. szerzej na ten temat: K. Puzio, Wieczory badeńskie, czyli „Powieści o strachach i upiorach” Józefa Maksymiliana Hrabi z Tenczyna Ossoliniskiego, „Wiek Oświecenia” 2007.

${ }^{46}$ Zob. A. Gollnikowa, Elementy grozy w „Nie-bajkach” Henryka Rzewuskiego, „Zeszyty Naukowe Wyzszej Szkoły Pedagogicznej w Bydgoszczy” 1994, z. 36: „Studia Filologiczne”, s. 43-52.

${ }^{47}$ B. Dopart, Aneks. Pouvieść gotycka - politypiczność gatunku, w: idem, Romantyzm polski: pluralizm pradów i synkretyzm dzieła, Kraków 1999, s. 191.

${ }^{48}$ Por. A. Waśko, Wstęp, w: Romantyczna gavęda szlachecka..., op. cit., s. XI.

$49 \mathrm{Na}$ gruncie naszej dziewiętnastowiecznej literatury powstała właściwie tylko jedna „prawdziwa” powieść gotycka, pomijana w dotychczasowej tradycji badawczej gatunku. Są to gotycko-sarmackie Zawieprzyce Aleksandra Bronikowskiego, wydane po polsku w roku 1828. Tak jak Rękopis znaleziony $w$ Saragossie Potockiego, który Maria Janion z pewnymi zastrzeżeniami zalicza do tego gatunku, zostały napisane w języku obcym - po niemiecku. Autor tej powieści w sposób absolutnie unikalny, a przede wszystkim z nieporównanie lepszym skutkiem niż Anna Mostowska w Moich rozrywkach, połączył inspiracje europejskiego gotycyzmu z polską tradycją podaniową osnutą wokół rzeczywiście istniejącego w województwie lubelskim, nad rzeką Wieprz, zamku, kryjącego tajemnicę okrutnych zbrodni popełnionych przez tamtejszego dziedzica. 